\title{
Analisis Produksi Kepiting Bakau (Scylla seratta) Kabupaten Bone
}

\author{
Masitah $^{\mathrm{a}}$, Didi Rukmana ${ }^{\mathrm{b}}$, Budimawan ${ }^{\mathrm{c}}$ \\ ${ }^{a}$ Fakultas Pertanian, Universitas Sembilanbelas November Kolaka, Sulawesi Tenggara Indonesia, email: masitah@usn.ac.id \\ ${ }^{b}$ Fakultas Pertanian, Universitas Hasanuddin, Makassar, Indonesia, email: drukmana@unhas.ac.id \\ ${ }^{c}$ Fakultas Ilmu Kelautan dan Perikanan, Universitas Hasanuddin, Makassar, Indonesia, email: budimawan@yahoo.com
}

\section{Article Info}

\section{Article history:}

Received 5 Agustus 2019

Received in revised form 13 Agustus 2019

Accepted 8 September 2019

DOI

https://doi.org/10.32938/ag.v4i4.817

Keywords:

Produksi

Kepiting Bakau

Cobb-Douglas

\section{Abstrak}

Salah satu daerah penghasil kepiting bakau terbesar di Kabupaten Bone adalah Kecamatan Cenrana. Peningkatan jumlah produksi kepiting bakau pada tahun 2016 adalah sumbangsi terbesar dari Kecamatan Cenrana. Akan tetapi, seiring permintaan kepiting bakau di Kabupaten Bone terus meningkat, jumlah produksinya belum mampu memenuhi permintaan pasar kepiting bakau meskipun produksinya pernah mengalami peningkatan. Penelitian ini bertujuan untuk menganalisis pengaruh input produksi (lahan tambak, benih, pakan dan tenaga kerja) terhadap produksi kepiting bakau. Penelitian ini dilaksanakan di Kecamatan Cenrana, Kabupaten Bone, Penentuan lokasi dilakukan secara sengaja (purvosive). Penelitian ini dilaksanakan pada Bulan Februari sampai dengan Maret 2018. Responden dalam penelitian in adalah petani kepiting bakau yang dipilih menggunakan metode sampling sebanyak 92 orang. Adapun analisis data yang digunakan yaitu analisis regresi berganda dengan metode Ordinary Least Square (OLS), model yang digunakan adalah persamaan fungsi produksi CobbDouglas. Hasil penelitian menunjukkan bahwa peningkatan produksi kepiting bakau dipengaruhi oleh faktor lahan tambak $(0,231)$, benih $(0,459)$, pakan $(0,155)$ dan tenaga kerja $(0,238)$ dan berpengaruh positif dan signifikan terhadap produksi kepiting bakau. Produksi kepiting bakau akan semakin meningkat karena ada potensi peningkatan produksi kepiting bakau dengan adanya kepastian ketersediaan benih melalui perbaikan habitat mangrove yang lebih baik, peraturan penangkapan induk kepiting bakau yang bertelur dan perbaikan lingkungan akibat pencemaran disekitar hulu Sungai Cenrana Kabupaten Bone.

\section{Pendahuluan}

Kepiting bakau (Scylla seratta) merupakan salah satu diantara komoditi perikanan laut yang mempunyai nilai ekonomis tinggi di pasaran dunia. Sangat digemari konsumen lokal maupun luar negeri dan dalam kurun Komoditas in mempunyai kandungan nilai gizi tinggi, protein dan lemak, bahkan pada telu kepiting kandungan proteinnya sangat tinggi, yaitu sebesar $88,55 \%$. Dengan nila komposisi demikian, komoditas ini sangat digemari konsumen luar negeri dan menjadi salah satu makanan paling bergengsi di kalangan mereka. Amerika Serikat merupakan negara penyerap hampir 55\% produksi kepiting dunia, sedang permintaan lainnya datang dari negara-negara di kawasan Eropa, Australia Jepang, Hongkong, Taiwan, Singapura, Korea Selatan.

Kabupaten Bone adalah salah satu daerah sentra produksi kepiting bakau yang memiliki potensi untuk melakukan budidaya terutama budidaya kepiting bakau. Komoditas kepiting bakau telah lama dikenal oleh masyarakat melalui usaha penangkapan. Usaha kepiting bakau telah cukup lama dilakukan untuk memenuhi kebutuhan pasar domestik. Namun sejak tahun 1990, ketika ekspo kepiting bakau mulai dilakukan maka kegiatan ini mulai meningkat dan berkembang menjadi usaha budidaya kepiting bakau. Usaha budidaya ini banyak ditemui di beberapa Kecamatan, khususnya di daerah yang memiliki pantai seperti Kecamatan Tanete Riattang Timur, Cenrana, Awangpone dan Tellu Siattinge yang memiliki potensi lahan tambak cukup luas \pm 3.000 ha dan $75 \%$.

Jenis kepiting bakau yang dikembangkan di Kabupaten Bone merupakan salah satu komoditi unggulan daerah. Komoditi ini sudah terkenal dan pemasarannya sudah cukup luas hingga diekspor ke beberapa negara diantaranya Sanghai, Taiwan, Hongkong dan Singapura. Menurut Dinas Kelautan dan Perikanan Kabupaten Bone (2017) data produksi kepiting bakau di Kabupaten dapat dilihat pada Gambar 1.

\section{Gambar}

Produksi Komoditi Kepiting Bakau di Kabupaten Bone Tahun 2017
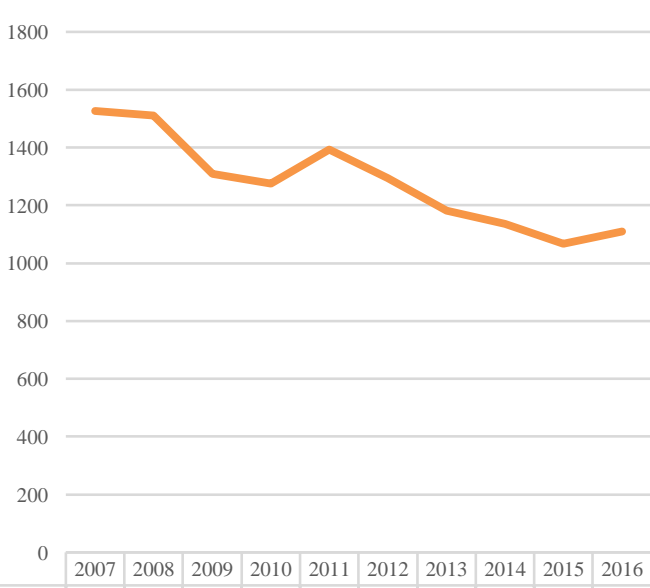

Gambar 1 menjelaskan bahwa salah satu daerah penghasil kepiting bakau terbesar di Kabupaten Bone adalah Kecamatan Cenrana. Peningkatan jumlah produksi kepiting bakau pada tahun 2016 adalah sumbangsih terbesar dari Kecamatan Cenrana. Akan tetapi, seiring permintaan kepiting bakau di Kabupaten Bone terus meningkat, jumlah produksinya belum mampu memenuh permintaan pasar kepiting bakau meskipun produksinya pernah mengalami peningkatan. Hal ini disebabkan oleh beberapa faktor diantaranya penggunaan input-input atau faktor produksi kurang efisien sehingga produksi tidak maksimal. Adapun kendala yang dihadapi petani kepiting bakau dalam hal produksi yaitu ketersediaan benih kepiting yang kurang karena pasokan benih masih tergantung pada alam (musim) sehingga benih yang digunakan dalam budidaya kepiting pun hasil tangkapan dari alam bukan hasil pembenihan Meskipun kepiting bakau sudah berhasil dibenihkan secara buatan, namun berbagai keterbatasan membuat sebagian besar petani kepiting bakau di Kabupaten Bone masih mengandalkan pasokan benihnya dari hasil penangkapan. Berdasarkan uraian tersebut, maka dapat dirumuskan permasalahan sebagai berikut yakni sejauh mana pengaruh input produksi (luas tambak, benih, pakan dan tenaga kerja) terhadap produksi kepiting bakau terkhusus pada masalah penurunan produksi kepiting bakau di Kabupaten Bone.

\section{Metode}

Pemilihan lokasi penelitian dilakukan dengan pertimbangan volume dan nilai produksi terbesar kepiting bakau di Kabupaten Bone, hal ini dapat dilihat pada tabel 1 .

Tabel 1.Volume dan Nilai Produksi Budidaya Kepiting Bakau di Kabupaten Bone Tahun 2016.

\begin{tabular}{clcc}
\hline No. & Kecamatan & $\begin{array}{c}\text { Volume } \\
\text { (Ton) }\end{array}$ & Nilai ( x 1.000,-) \\
\hline 1 & Awangpone & 112,7 & 6.763 .800 \\
2 & Cenrana & 612,7 & 36.764 .400 \\
3 & Tanete Riattang Timur & 140,0 & 8.400 .000 \\
4 & Tellu Siattinge & 245,0 & 14.701 .800 \\
\hline \multicolumn{1}{c}{ Jumlah } & $\mathbf{1 . 1 1 0 , 5}$ & $\mathbf{6 6 . 6 3 0 . 0 0 0}$
\end{tabular}

Sumber: Dinas Kelautan dan Perikanan Kabupaten Bone, 2017.

Tabel 1. menunjukkan bahwa volume dan nilai produksi terbesar terdapat pada Kecamatan Cenrana Kabupaten Bone yang merupakan salah satu sentra produksi kepiting bakau di Sulawesi Selatan. Penelitian ini dilaksanakan pada bulan Februari sampai dengan bulan Maret 2018.

Populasi petani kepiting bakau di Kabupaten Bone, Kecamatan Cenrana berjumlah 1.120 petani (RTP) seperti terlihat pada Tabel 2. Jumlah sampel ditentukan dengan menggunakan rumus slovin (Sevilla, 2007).

$$
n=\frac{N}{1+N \cdot e^{2}}
$$

Dimana:

$\mathrm{n} \quad=$ Jumlah sampel

$\mathrm{N}=$ Jumlah populasi petani (RTP) kepiting bakau

e $\quad=$ tingkat kesalahan pengambilan sampel $(10 \%)$
Sehingga jumlah sampel dalam penelitian ini adalah 92 orang petani kepiting bakau. Adapun desa yang terpilih adalah desa yang memiliki RTP 
terbanyak sebanyak 6 desa yakni desa Latonro, Cakkeware, Pallime, Ajalasse, Pusungnge dan Panyiwi.

Tabel 2. Data Rumah Tangga Petani dan Luas Tambak Kecamatan Cenrana Tahun 2017.

\begin{tabular}{clcc}
\hline No. Nama Desa & $\begin{array}{c}\text { Rumah Tangga Perikanan } \\
\text { (RTP) }\end{array}$ & $\begin{array}{c}\text { Luas Tambak } \\
\text { (Ha) }\end{array}$ \\
\hline 1 Pallime & 122 & 363.92 \\
2 & Laoni & 56 & 203.00 \\
3 & Latonro & 281 & 409.24 \\
4 & Labotto & 27 & 83.50 \\
5 & Pallae & 55 & 99.30 \\
6 & Kel. Cenrana & 34 & 59.00 \\
7 & Cakkeware & 174 & 911.40 \\
8 & Awang Cenrana & 44 & 109.50 \\
9 & Ajalasse & 102 & 215.98 \\
10 & Pusungnge & 89 & 326.45 \\
11 & Panyiwi & 81 & 196.00 \\
12 & Naga Uleng & 55 & 119.00 \\
\hline \multicolumn{2}{c}{ Jumlah } & $\mathbf{1 . 1 2 0}$ & $\mathbf{3 0 9 6 . 2 9}$ \\
\hline
\end{tabular}

Sumber: Dinas Kelautan dan Perikanan Kabupaten Bone. 2017.

Untuk mengetahui faktor-faktor yang mempengaruhi produksi kepiting bakau di Kabupaten Bone digunakan analisis regresi berganda dengan metode Ordinary Least Square (OLS). Model yang digunakan adalah persamaan fungsi produksi Cobb-Douglas sebagai berikut :

$$
\ln Y_{Q}=\ln a+b_{1} \ln x_{1}+b_{2} \ln x_{2}+b_{3} \ln x_{3}+b_{4} \ln x_{4}
$$

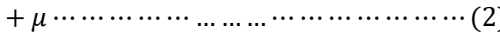

Keterangan :

$\begin{array}{ll}\mathrm{Y}_{\mathrm{Q}} & =\text { Produksi Kepiting Bakau }(\mathrm{Kg}) \\ \mathrm{a} & =\text { nilai konstanta } \\ \mathrm{b}_{1}, \mathrm{~b}_{2}, \mathrm{~b}_{3}, \mathrm{~b}_{4}, \mathrm{~b}_{5} & =\text { Koefisien regresi } \\ \mathrm{x}_{1} & =\text { Luas Tambak }(\mathrm{Ha}) \\ \mathrm{x}_{2} & =\text { Benih }(\text { ekor) } \\ \mathrm{x}_{3} & =\text { Pakan }(\mathrm{kg}) \\ \mathrm{x}_{4} & =\text { Tenaga Kerja }(\mathrm{HOK})\end{array}$

Sebutkan kapan dan dimana penelitian dilakukan, metode, prosedur dan teknik analisis data yang digunakan ditulis dengan jelas dan sistematis disertai dengan bahan dan alat yang digunakan pada setiap bagian prosedur. Berikan detail yang cukup untuk memungkinkan metode dilakukan ulang oleh pihak lain. Metode yang telah dipublikasikan harus ditunjukkan dengan sumber pustakanya, hanya modifikasi yang relevan yang harus dijelaskan. Jelaskan apakah penelitian ini eksperimental atau eksplorasi.

\section{Hasil dan Pembahasan}

Input produksi yang menjadi kebutuhan utama dalam menjalankan usaha budidaya kepiting bakau adalah ketersediaan bibit atau benih kepiting. Kondisi riil di Kecamatan Cenrana menunjukkan bahwa benih kepiting hanya diperoleh berdasarkan hasil tangkapan dari alam, hal ini menyebabkan sangat sulit tercapai kontinuitas produksi dalam usaha budidaya kepiting bakau. Permintaan dari pembeli biasanya menekankan pada kontinuitas produksi dan kualitas yang konsisten sehingga kendala dalam hal ketersediaan benih sangat dirasakan bagi pembudidaya. Hal ini menyebabkan pembudidaya belum bisa memenuhi permintaan pasar terutama dari luar negeri meskipun harga yang ditawarkan sangat tinggi.

Data dari responden menyebutkan bahwa produksi budidaya kepiting bakau di Kabupaten Bone selalu terserap oleh pasar dengan harga yang relatif tinggi, namun di sisi lain pembudidaya kesulitan meningkatkan kapasitas produksinya karena keterbatasan input produksi. Berbagai kendala yang disebutkan membuat peluang pengembangan budidaya kepiting bakau yang masih prospektif di Kabupaten Bone belum optimal dimanfaatkan dalam tujuan peningkatan kesejahteraan masyarakat dalam hal ini pendapatan petan kepiting bakau. Untuk pengujian hasil penelitian yang dilakukan dapat dilihat pada uji klasik dan uji statistik yang telah dilakukan.

\subsection{Uji Asumsi Klasik}

Uji asumsi klasik digunakan untuk memberikan kepastian bahwa persamaan regresi yang digunakan memiliki ketepatan dalam estimasi, tidak bias dan konsisten yang meliputi uji normalitas, multikolineritas dan heteroskedastisitas sebagai berikut.

\section{Uji Normalitas}

Uji normalitas diperlukan untuk mengetahui apakah data yang kita gunakan berdistribusi normal atau tidak. Uji normalitas ini menggunakan aplikasi Eviews 9.0 melalui Histogram-Normaity Test. Apabila data memiliki nilai probability Jarque-Bera > Alpha 0,05, maka data dinyatakan berdistribusi normal.

Berdasarkan Gambar 2 menunjukkan bahwa nilai Jarque-Bera sebesar 0,120 dengan probabilitas $0,941>0,05$ (tingkat kepercayaan $95 \%$ ) yang berarti residual berdistribusi secara normal. Hasil analisis regresi menunjukkan bahwa model regresi yang digunakan adalah model yang baik karena salah satu syarat BLUE (Best Linear Unbiased Estimator) terpenuhi.

\section{Multikolineritas}

Multikolinieritas digunakan untuk menguji suatu model apakah terjadi hubungan yang sempurna atau hampir sempurna antara variabel bebas, sehingga sulit untuk memisahkan pengaruh antara variabel-variabel itu secara individu terhadap variabel terikat. Pengujian ini untuk mengetahui apakah antar variabel bebas dalam persamaan regresi tersebut tidak saling berkorelasi. Untuk mendeteksi multikolinieritas adalah dengan melihat nilai tolerance dan nilai Variance Inflation Factor (VIF), dimana menurut Hair et al dalam Duwi Priyatno (2009) variabel dikatakan mempunyai masalah multikolinearitas apabila nilai tolerance lebih kecil dari 0,1 atau nilai VIF lebih besar dari 10.
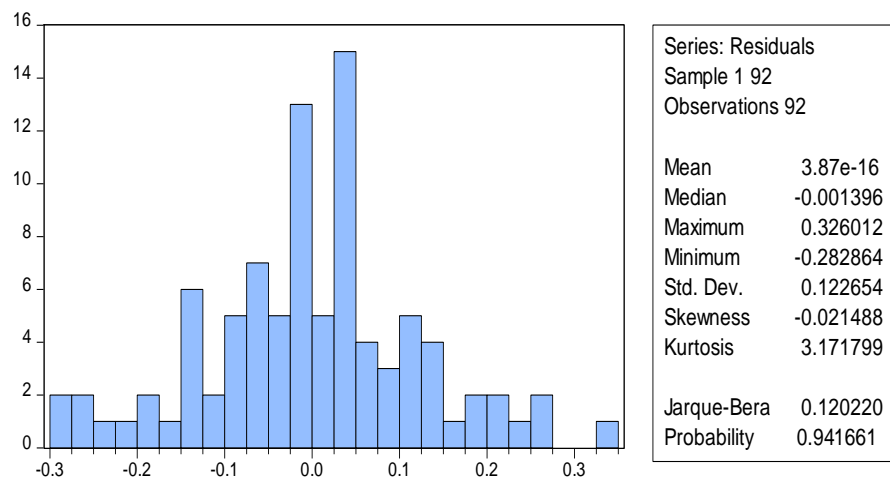

Gambar 2. Hasil Uji Normalitas Pengaruh Input Produksi Terhadap Produksi Kepiting Bakau

Tabel 3. Hasil Uji Multikolineritas Pengaruh Input Produksi Terhadap Produksi Kepiting Bakau

\begin{tabular}{clcc}
\hline No. & Variabel & Nilai VIF & Keterangan \\
\hline 1. & Luas Tambak & 7.248232 & Non Multikolinearitas \\
2. Benih & 5.549773 & Non Multikolinearitas \\
3. Pakan & 5.487365 & Non Multikolinearitas \\
4. Tenaga Kerja & 7.045741 & Non Multikolinearitas \\
\hline
\end{tabular}

Tabel 3 terlihat bahwa semua variabel memiliki nilai VIF kurang dari 10, sehingga dapat disimpulkan bahwa model regresi yang digunakan baik karena tidak ditemukan adanya masalah korelasi antar variabel independen atau tidak terjadi Multikolineritas.

3. Heteroskedastisitas

Uji Heteroskedastisitas dilakukan untuk mengetahui ada tidaknya sebaran varian yang sama pada residual. Untuk mengetahui ada tidaknya masalah heteroskedastisitas menggunakan uji White Heteroscedastisticity dalam program Eviews 9.0. jika nilai Prob. Chi-Squared pada Obs*R-Squared lebih besar dari alpha 0,05 maka model regersi tersebut bebas dari masalah heteroscedasticity. Model regresi dikatakan baik jika varians dari setiap variabel independen memiliki nilai yang homogen sehingga antar variabel tidak memiliki perbedaan yang cukup signifikan.

Tabel 4. Hasil Uji Heteroskedastisitas Pengaruh Input Produksi Terhadap Produksi Kepiting Bakau

\begin{tabular}{lclc}
\hline \multicolumn{4}{c}{ Heteroskedasticity Test : Breusch-Pagan-Godfrey } \\
\hline F-statistic & 2.460281 & Prob. F & 0.0512 \\
Obs*R-Squared & 9.349163 & Prob. Chi-Square & 0.0529 \\
\hline
\end{tabular}

Tabel 4 menunjukkkan bahwa nilai Prob. Chi-Squared pada Obs*RSquared sebesar 0,0529 lebih besar dari alpha 0,05 berarti model regresi bersifat homoskedastisitas atau dengan kata lain tidak ada masalah asumsi non heteroskedastisitas sehingga dapat disimpulkan bahwa data pada masing-masing variabel independen dalam model memiliki varians yang homogen.

Hasil uji asumsi klasik menunjukkan bahwa model regresi yang digunakan sudah bersifat BLUE (Best Linear Unbiased Estimator) karena telah berdistribusi normal, bebas dari masalah multikolinearitas dan heteroskedastisitas, sehingga dapat dilakukan analisis regresi linear berganda untuk mengetahui pengaruh input produksi terhadap produksi kepiting bakau di Kabupaten Bone.

\subsection{Uji Statistik}

Pengujian hipotesis faktor-faktor yang mempengaruhi produktivitas kedelai menggunakan analisis regresi linear berganda dengan menganalisis koefisien determinasi $\left(\mathrm{R}^{2}\right)$, Uji T dan Uji F. tingkat kepercayaan yang digunakan dalam penelitian ini adalah sebesar $95 \%$ dan $90 \%(\alpha=5 \%, \alpha=10 \%)$.

\section{Uji Koefisien Determinasi $\left(\mathbf{R}^{2}\right)$}

Uji koefisien determinasi digunakan untuk mengetahui besar pengaruh variabel-variabel independen terhadap variabel dependen. Semakin besar $\mathrm{R}^{2}$ semakin besar pengaruh model dalam menjelaskan variabel dependen. Nilai $R^{2}$ berkisar antara 0 sampai $1\left(0 \leq \mathrm{R}^{2} \leq 1\right)$ (Ghozali, 2012). Berdasarkan data pada Tabel 5 terlihat bahwa besarnya $\mathrm{R}^{2}$ adalah 0,964 yang berarti $96,4 \%$ variabel produksi kepiting bakau dapat dijelaskan keempat variabel independen yaitu lahan tambak, benih, pakan dan tenaga kerja. Sedangkan sisanya yakni 3,6\% dijelaskan oleh variabel diluar model. 
Tabel 5. Pengaruh Input Produksi Terhadap Produksi Kepiting Bakau

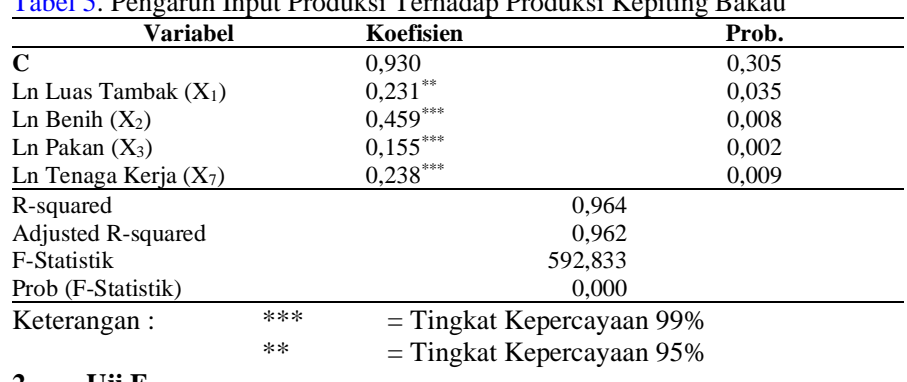

\section{Uji F}

Uji $\mathrm{F}$ atau uji koefisien secara serentak dilakukan untuk mengetahui pengaruh variabel independen secara serentak terhadap variabel dependen secara siginifikan atau tidak. Pada Tabel 5 terlihat bahwa nilai F-hitung adalah 592,833 dengan nilai probabilitas $<\alpha=1 \%$ yaitu 0,000 . Dengan demikian dapat disimpulkan bahwa variable independen luas tambak, benih, pakan dan tenaga kerja secara bersama-sama berpengaruh terhadap produksi kepiting bakau. Hal ini dapat dilihat jika terjadi penambahan luas tambak, maka jumlah penggunaan benih kepiting bakau harus ditambah pula sesuai dengan proporsi penambahan luas tambak. Dengan menambah jumlah benih berarti pakan yang dibutuhkan akan semakin banyak. Selain itu, dengan menambah luas tambak maka jumlah penggunaan tenaga kerja juga dapat bertambah walaupun penambahannya tidak terlalu signifikan seperti untuk benih dan pakan. Berdasarkan hal-hal tersebut dapat diketahui bahwa faktor-faktor produksi secara bersama-sama mempunyai peranan dalam meningkatkan produksi kepiting bakau di Kabupaten Bone.

3. Uji t

Uji t digunakan unuk mengetahui pengaruh masing-masing variabel independen terhadap variabel dependen. Pada Tabel 3 terlihat bahawa secara matematis, model regersi antara variabel produksi kepiting bakau dengan variabel faktor-faktor yang mempengaruhinya dapat dtuliskan dalam persamaan berikut.

$$
\begin{gathered}
\ln Y_{q}=0,930+0,231 \ln x_{1}+0,459 \ln x_{2}+0,155 \ln x_{3}+0,238 \ln x_{4} \\
+\mu \cdots \cdots \cdots \cdots \cdots \cdots \cdots \cdots \cdots \cdots(3)
\end{gathered}
$$

Dari semua variabel yang digunakan, keempat variabel bebas memiliki pengaruh signifikan terhadap produksi kepiting bakau yakni lahan tambak, benih, pakan dan tenaga kerja.

\section{Luas Tambak $\left(\mathbf{X}_{1}\right)$}

Lahan tambak merupakan salah satu faktor utama yang dibutuhkan dalam memproduksi kepiting bakau. Lahan tambak dibutuhkan sebagai tempat berlangsungnya proses produksi hingga pemanenan. Rata-rata luasan lahan yang digunakan oleh petani kepiting bakau di Kabupaten Bone untuk budidaya kepiting bakau sebesar 4,75 Ha.

Tabel 5 terlihat bahwa luas tambak berpengaruh secara signifikan terhadap produksi kepiting bakau pada tingkat kepercayaan $95 \%$ dan $90 \%$ karena p-value luas tambak sebesar 0,035 lebih kecil dari $\alpha$ yaitu 0,1 . Nilai koefisien regresinya sebesar 0,231 , bernilai positif artinya setiap penambahan luas lahan tambak sebesar 1 persen akan meningkatkan produksi kepiting bakau sebesar 0,231 persen dengan asumsi faktor lain tetap (konstan).

Hal ini sesuai dengan penelitian yang dilakukan oleh Andriyanto et al (2013) semakin luas lahan tambak yang digunakan maka semakin besar persentase udang yang hidup sehingga produksi yang diperoleh besar. Begitu pula dengan penelitian yang dilakukan oleh Sutiah (2008) bahwa dengan menambah luasan kolam maka petani ikan dapat menambah jumlah induk ikan nila sehingga akan semakin banyak benih ikan nila yang dihasilkan pada setiap siklusnya. Hal ini menunjukkan bahwa petani masih dapat menambah jumlah luas kolam untuk memperoleh produksi maksimal.

Berdasarkan hasil survei langsung, petani responden yang memiliki luas lahan tambak yang besar, akan menghasilkan produksi kepiting bakau yang lebih banyak. Hal ini karena jumlah kepiting bakau yang dapat dipelihara dalam luasan lahan tambak yang besar lebih banyak dibandingkan dengan luasan lahan tambak yang kecil. Begitu pula dengan penggunan luas tambak petani responden di Kabupaten Bone, ketika penggunaan luas tambak dilakukan secara optimal dalam penggunaannya akan mengakibatkan produksi kepiting bakau juga meningkat.

\section{Benih $\left(\mathbf{X}_{2}\right)$}

Benih yang digunakan oleh petani responden adalah benih hasil dari tangkapan langsung oleh petani di alam dan dari pedagang benih kepiting bakau (padakkang). Rata-rata penggunaan input produksi berupa benih yang digunakan oleh petani kepiting bakau di Kabupaten Bone untuk budidaya kepiting bakau sebesar 4163 ekor benih kepiting bakau.

Hasil Uji t statistik pada Tabel 5 menunjukkan bahwa benih berpengaruh signifikan terhadap produksi kepiting bakau pada tingkat kepercayaan $99 \%$ dengan p-value 0,002 lebih kecil dari $\alpha$ yaitu 0,1 . Nilai koefisien regresinya sebesar 0,459 , bernilai positif artinya setiap penambahan jumlah benih sebesar 1 persen akan meningkatkan produksi kepiting bakau sebesar 0,459 persen dengan asumsi faktor lain tetap (konstan).

Hal ini sesuai dengan penelitian yang dilakukan oleh Sutiah (2008) bertambahnya jumlah induk ikan maka produksi benih ikan yang dihasilkan juga akan ikut bertambah. Penambahan induk ini tentunya harus dibarengi pula dengan penambahan luas kolam agar tidak terjadi kepadatan. Kepadatan jumlah induk dalam kolam akan menyebabkan induk menjadi stress sehingga kemampuan induk dalam bertelur menurun, selain itu juga dapat menyebabkan kematian. Benih merupakan salah satu faktor produksi penting dalam budidaya kepiting bakau. Ketersediaan benih kepiting bakau merupakan salah satu faktor yang menentukan produksi kepiting bakau (KKP, 2015). Hal ini juga sejalan dengan penelitian yang dilakukan oleh Nasution (2014) menyatakan bahwa variabel bibit yang berpengaruh positif dan signifikan terhadap produksi kepiting soka (Scylla $s p$ ) di Kecamatan Sei Lepan Kabupaten Langkat, dengan penambahan satu unit bibit kepiting soka akan meningkatkan produksi kepiting soka.

Berdasarkan hasil wawancara dengan petani responden, semakin banyak jumlah benih yang digunakan, maka semakin banyak juga kepiting bakau yang akan dihasilkan. Jumlah kepiting bakau yang dihasilkan tergantung dari jumlah dan kualitas benih yang digunakan. Berdasarkan hasil riil penelitian, benih merupakan faktor utama dalam usaha budidaya kepiting bakau. Ketika ketersediaan benih kepiting bakau berkurang akan mengakibatkan kelangkaan dan harga benih kepiting bakau akan semakin tinggi dan petani responden akan tetap mengambil resiko membeli benih kepiting bakau tersebut untuk tetap menjalankan usaha budidaya kepiting bakau. Budidaya kepiting bakau di Kabupaten Bone masih dihadapkan dengan keterbatasan populasi benih kepiting bakau di alam. Kendala yang dihadapi adalah masih belum dikuasainya teknologi modern budidaya kepiting bakau sehingga teknologi yang diterapkan masih bersifat tradisional. Ketersediaan benih bersumber dari tangkapan alam sehingga kontinuitas volume produksi belum dapat terjamin. Untuk mengatasi persoalan keterbatasan benih alam yang terus berkurang, maka teknik perbenihan kepiting bakau dapat diperkenalkan sebagai solusi mengatasi masalah perbenihan kepiting bakau. Selain itu teknologi lain yang dapat disosialisasikan adalah teknologi hatchery (pembibitan) kepiting bakau. Teknologi hatchery diharapkan dapat mengatasi kelangkaan benih kepiting yang selama ini hanya tersedia di alam.

\section{Pakan $\left(\mathbf{X}_{3}\right)$}

Pakan merupakan makanan bagi kepiting bakau yang diberikan secara teratur. Pemberiaan jumlah, waktu, dan jenis pakan akan sangat berpengaruh pada pertumbuhan kepiting bakau. Besaran penggunaan pakan yang digunakan adalah kilogram $(\mathrm{kg})$. Permasalahan yang sering terjadi pada budidaya kepiting bakau (Scylla serrata), khususnya pada budidaya semi-intensif di Kabupaten Bone adalah dari segi pakan, yakni diperlukannya pakan alternatif yang memilki kandungan nutrisi yang cukup tinggi dan baik guna mendukung pertumbuhan kepiting, sementara selama ini budidaya kepiting bakau masih mengandalkan ikan curah sebagai pakan.

Hasil Uji t statistik pada Tabel 5 menunjukkan bahwa pakan berpengaruh signifikan terhadap produksi kepiting bakau pada tingkat kepercayaan $99 \%$ dengan p-value 0,002 lebih kecil dari $\alpha$ yaitu 0,01 . Nilai koefisien regresinya sebesar 0,155 , yang artinya setiap penambahan jumlah pakan sebesar 1 persen akan meningkatkan produksi kepiting bakau sebesar 0,155 persen dengan asumsi faktor lain tetap (konstan).

Pada penelitian yang dilakukan oleh Tahe (2011), menunjukan bahwa kombinasi pakan berpengaruh nyata $(\mathrm{P}<0.05)$ terhadap pertumbuhan, sinasitas, rasio konversi pakan, dan produksi udang vaname. Menurut Fadnan (2010) menyatakan bahwa kegiatan paling penting dalam budidaya perikanan adalah pemberian pakan, agar pertumbuhan kepiting yang dibudidayakan dapat tumbuh dengan baik, maka pakan yang diberikan harus memenuhi kualitas dan cukup jumlahnya. Pemberian pakan dalam jumlah yang tepat akan memberikan pertumbuhan optimum bagi kepiting bakau.

Berdasarkan hasil wawancara dengan petani responden, pakan merupakan salah satu faktor penentu keberhasilan budidaya kepiting bakau yakn ketersediaan pakan. Secara alamiah pakan kepiting bakau adalah jenis bangkai ikan dan sesama jenis (kanibal). Pemberian pakan adalah hal yang mutlak dilakukan dalam kegiatan budidaya kepiting bakau untuk menghasilkan kepiting bakau yang berkualitas. Akan tetapi beberapa petani responden tidak terlalu memperhatikan dari banyaknya penggunaan pakan yang mereka gunakan. Penggunaan pakan yang baik dan benar dapat meningkatkan produksi dan kualitas kepiting bakau.

\section{Tenaga Kerja $\left(\mathbf{X}_{4}\right)$}

Tenaga kerja dalam penelitian ini berasal dari dalam keluarga maupun diluar keluarga. Tenaga kerja tersebut digunakan dalam proses budidaya mulai dari persiapan lahan, pembenihan, pemberian pakan, pemeliharaan, panen dan pasca panen. Hasil uji statistik pada Tabel 5 menunjukkan bahwa tenaga kerja memiliki pengaruh secara signifikan terhadap produksi kepiting bakau pada tingkat kesalahan 95\% dan 90\% karena p-value sebesar 0,009 lebih kecil dari $\alpha$ 0,1 . Nilai koefisien regresinya sebesar 0,238 , yang artinya setiap penambahan jumlah tenaga kerja sebesar 1 persen akan meningkatkan produksi kepiting bakau sebesar 0,238 persen dengan asumsi faktor lain tetap (konstan).

Hal ini sejalan dengan penelitian yang dilakukan oleh Sutiah (2008) bahwa faktor produksi tenaga kerja secara nyata berpengaruh terhadap produksi benih ikan nila yang dihasilkan. Tenaga kerja sangat dibutuhkan dalam melakukan budidaya, namun jumlah waktu yang diperlukan tidak terlalu lama setiap harinya. Hal ini diduga dengan bertambahnya jumlah tenaga kerja maka produksi benih ikan yang dihasilkan juga akan ikut bertambah. Penambahan tenaga kerja ini tentunya harus dibarengi pula dengan penambahan luas kolam dan bibit ikan. Begitu pula dengan penelitian yang dilakukan oleh Fahry (2014) bahwa jika tenaga kerja meningkat 1 persen maka produksi ikan nila meningkat sebesar 0,0398 persen, cateris paribus. Hal ini berarti bahwa tenaga kerja berpengaruh positif dan signifikan secara parsial terhadap produksi ikan nila di 
Kelurahan Koya Timur pada tingkat kepercayaan 95 persen. Semakin banyak tenaga kerja yang digunakan maka semakin produksi semakin meningkat, secara otomatis penerimaan petani akan semakin besar pula.

Berdasarkan hasil wawancara dengan petani responden bahwa sumber tenaga kerja yang digunakan oleh petani responden sebagian besar berasal dari Tenaga Kerja Dalam Keluarga (TKDK) dan hanya dilakukan oleh laki-laki. Biasanya biaya untuk TKDK tidak diperhitungkan oleh petani responden karena berasal dari dalam keluarganya sendiri. Alasan petani memilih untuk tidak menggunakan Tenaga Kerja Luar Keluarga (TKLK) karena kegiatan-kegiatan budidaya yang dilakukan tidak rumit dan berat serta tidak memerlukan tenaga yang besar. Penggunaan tenaga kerja secara optimal dan sesuai dengan kebutuhan budidaya kepiting bakau dapat meningkatakan hasil produksi kepiting bakau. Selain itu, keterampilan yang dimiliki oleh tenaga kerja merupakan hal yang paling utama dilimiliki khususnya dalam usaha budidaya kepiting bakau, baik keterampilan diperoleh dari pelatihan yang diselenggarakan oleh pemerintah atau swasta maupun keterampilan yang diperoleh secara otodidak yakni pengalaman dilapangan. Untuk menghasilkan tenaga kerja yang berkualitas dibutuhkan penggabungan dari dua jenis keterampilan (soft skill) dari petani yakni keterampilan yang dimiliki sejak lahir dan keterampilan yang diperoleh dari beberapa pelatihan yang diikutinya.

\section{Simpulan}

Peningkatan Produksi kepiting bakau dipengaruhi oleh faktor lahan tambak $(0,231)$, benih $(0,459)$, pakan $(0,155)$ dan tenaga kerja $(0,238)$ dan berpengaruh positif dan signifikan terhadap produksi kepiting bakau. Produksi kepiting bakau akan semakin meningkat karena ada potensi peningkatan produksi kepiting bakau dengan adanya kepastian ketersediaan benih melalui perbaikan habitat mangrove yang lebih baik, peraturan penangkapan induk kepiting bakau yang bertelur dan perbaikan lingkungan akibat pencemaran disekitar hulu Sungai Cenrana Kabupaten Bone.

\section{Pustaka}

Andriyanto F, Efani A, Riniwati H. 2018. Analisis Faktor-Faktor Produksi Usaha Pembesaran Udang Vanname (Litopenaeus Vannamei) Di Kecamatan Paciran Kabupaten Lamongan Jawa Timur; Pendekatan Fungsi Cobb-Douglass. Jurnal ECSOFiM 1(1):82-96.

Dinas Kelautan dan Perikanan Kabupaten Bone, 2017. Volume Produksi Budidaya Kepiting Bakau. Kabupaten Bone.

Dinas Kelautan dan Perikanan Kabupaten Bone. 2017. Produksi Komoditi Kepiting Bakau di Kabupaten Bone. Kabupaten Bone.

Dinas Kelautan dan Perikanan Kabupaten Bone, 2017. Data Rumah Tangga Petani dan Luas Tambak Kecamatan Cenrana Tahun 2016. Kabupaten Bone.

Fadnan M, H. Iromo, A Hamzah 2010. Pengaruh Padat Tebar yang Berbeda terhadap Pertumbuhan dan Kelangsungan Hidup pada Penggemukan Kepiting Bakau (Scylla sp.). Jurnal Harpodon Borneo 3(2): 61-69.

Fahry, Z T, Kuwat S, Sarlota A R. 2014. Analisis Pengaruh Luas Lahan, Tenaga Kerja, Bibit, Pakan Dan Pupuk Terhadap Produksi Ikan Nila Di Kelurahan Koya Timur Distrik Muara Tami. Jurnal Kajian Ekonomi dan Studi Pembangunan 1(3):52-67

Ghozali, I. 2012. Model Persamaan Struktural: Konsep dan Aplikasi Dengan Program Amos 16.0. Badan Penerbit Universitas Diponegoro. Semarang.

Kementrian Negara Kelautan dan Perikanan. 2015. Keputusan Nomor 1/Permenkp/2015 tentang penangkapan lobster (Panulirus spp.), kepiting (Scylla spp.), dan rajungan (Portunus pelagicus spp.). KKP RI. $5 \mathrm{hlm}$.

Nasution I, Rahmanta, Akbar S. 2014. Analisis Produksi Dan Pendapatan Usaha Budidaya Kepiting Soka (scylla sp) di Kecamatan Sei Lepan Kabupaten Langkat. Agrica (Jurnal Agribisnis Sumatera Utara) 7(1):87-98.

Priyatno, D. 2013. Mandiri Belajar Analisis Data Dengan SPSS. Yogyakarta: Mediakom.

Sevilla, C.G. 2007. Research Methods. Quezon City: Rex Printing Company. Halaman 42.

Sutiah, E. 2008. Optimalisasi Produksi Usaha Pembenihan Ikan Nila Gift Di Kabupaten Sukabumi. [Tesis] Institut Pertanian Bogor: Bogor.

Tahe, D. 2011. Hubungan Jenis Ikan sebagai Pakan dan Tingkat Pemberiannya dengan Pertumbuhan Kepiting Bakau. [Tesis] Institiut Pertanian Bogor: Bogor. 